\title{
Chemical Properties, Biological Activities and Poisoning Treatment of Novichok: A Review
}

\author{
Tesia Aisyah Rahmania ${ }^{1}$, Bantari Wisynu Kusuma Wardhani ${ }^{1}$, Editha Renesteen ${ }^{1^{*}}$, \\ Yahdiana Harahap ${ }^{1,2}$ \\ ${ }^{1}$ Faculty of Military Pharmacy, Indonesia Defense University, Bogor. West Java. Indonesia \\ ${ }^{2}$ Faculty of Pharmacy, Universitas Indonesia, Depok. West Java. Indonesia
}

\begin{abstract}
Novichok is an organophosphate compound found as a nerve agent chemical weapon. However, the information about its chemical properties, biological activities, and molecular interactions in the body are still protected under the "top secret" security clearance. Novichok, with the codes A230, A232 and A234, is a compound whose structure has been successfully determined. The compound is synthesized from a precursor through a nucleophilic substitution reaction. Novichok agents are considered more potent than VX gas and can be applied in unitary and binary forms. This compound has ability for the binding with acetylcholinesterase (AChE) due to inability of acetylcholine metabolism. AChE catalyzes the rapid hydrolysis of acetylcholine to acetate and choline. The treatment of Novichok agent poisoning is similar to management of other nerve agents, such as atropine and pralidoxime administered intravenously. In this paper, we reviewed the Novichok component from chemical and biological perspective. Moreover, we discussed the potential molecular interaction and treatment of this compound.
\end{abstract}

Keywords: Novichok; chemical weapon; acetylcholinesterase (AChE); nervous system

*corresponding author

Email: editha.renesteen@idu.ac.id

\section{INTRODUCTION}

The efforts to eradicate chemical warfare agents (CWAs) by the Chemical Weapons Convention (CWC) have been performed, even though recent incidents involving nerve agents still occur (Nepovimova et al., 2018, Franca et al., 2019). For example, the Syrian civil war used sarin, and the assassination of Kim Jong-Nam (half-brother of Kim Jong-Un) used Venomous agent X (VX) last February 2017. Organization for Prevention of Chemical Weapons (OPCW) stated that the chemical used for these cases belonged to nerve agent compounds, one of the chemical weapons (CWs) (Franca et al., 2019). The research on synthetic insecticides was launched in 1934 by Otto Bayer, and the project was assigned by Gerhard Schrader. Two years later, Schrader turned the interest to organophosphorus compounds, leading to the synthesis of more than 2000 compounds, including tabun, highly toxic ethyl dimethyl-phosphoramidocyanidate (Szinicz, 2005).

Between 1973 and 1976, there is a top-secret Soviet project called FOLIANT with the main aim to synthesize the third generation of NAs with higher toxicity compared to the previous agents (Nepovimova et al., 2018). There were at least three chemical weapons synthesized, in particular A230, A232, and A234. The shortcoming of these agents was the low stability in the environment, which could be handled when the binary form of the agents is developed and passing the stability requirement. It turns out there were at least five types of binary A-agents with the code name NOVICHOK (Mirzayanov, 2009).

On 4 March 2018, there was an episode where Sergi Skripal, a former Russian military intelligence officer and his daughter collapsed on a park bench in Salisbury in the United Kingdom. The symptoms were nerve agent poisoning, confirmed with the biological sampling turned out the presence of Novichok (Chai et al., 2018). This chemical was identified by experts at the defense and science laboratory in Porton Down, England (Vale et al., 2018). These CWAs are highly potent nerve agents developed as part of the Russian classified nerve agent program, FOLIANT (Chai et al., 2018). In this paper, we reviewed the Novichok components from chemical and biological perspectives. Moreover, we discussed the potential molecular interaction and treatment of this poisoning compound.

\section{CHEMICAL PROPERTIES OF NOVICHOK}

Novichok is an organophosphate class compound that could attack nerves and causes death. Prior to Novichok, there were several nerve agent compounds belong to organophosphate group in Figure 1. These compounds are classified into $\mathrm{G}$ agents (tabun, sarin, soman) and $\mathrm{V}$ agent (VX, Russian VX, Chinese VX) (Karczmar, 1970). 
<smiles>CCOP(=O)(C#N)N(C)C</smiles>

Tabun<smiles>CC(C)OS(C)(=O)=O</smiles>

Sarin<smiles>CC(OP(C)(=O)F)C(C)(C)C</smiles>

Soman<smiles>CCOP(C)(=O)SCCN(C(C)C)C(C)C</smiles>

VX agent<smiles></smiles>

Russian VX<smiles></smiles>

Chinese VX

Figure 1. Organophosphate group nerve agent compounds

Although many have conducted research on the analysis, synthesis, and design of Novichok, the exact data about this compound is still not reported yet. Novichok is a binary weapon, containing toxic agents in its active state as chemical precursor in Figure 2. These precursors are less hazardous, simple in handling and more stable. Several series of Novichok compounds are known to have precursors, such as A232 and A234, which have Novichok precursors 5 and 7 (Brooks et al., 2018).<smiles>CC1COP(F)O1</smiles>

Novichok 5<smiles>CC1OP(F)OC1C</smiles>

Novichok 7
Figure 2. Novichok's precursors

The possible mechanism of synthesis Novichok can be seen in Figure 3. The precursor of Novichok can be made by reacting phosphorus trichloride with diol compounds to release the $\mathrm{HCl}$. The compound that is formed is then carried out by a nucleophilic substitution reaction, generating a change in the chlorine atom to fluorine to form precursor fluoro-1,3,2-dioxaphospholanes. Furthermore, when reacted with dichloro(fluoro)nitrosomethane, this precursor will form a stable intermediate compound at $-40^{\circ} \mathrm{C}$. If the temperature in the synthesis reaction is made more than $0^{\circ} \mathrm{C}$, a nucleophilic reaction will be formed by chloride anions, causing the phospholane ring to open (Ellison, 2016, Halámek \& Kobliha 2007).

The mechanism of action of Novichok attacks on the nervous system through the active side of acetylcholinesterase (AChE) which consists of Ser-HisGlu (Hoenig, S.L 2007). The hydroxyl group in serine acts as a nucleophilic which rapidly attacks the phosphate groups in the Novichok, thereby releasing fluoride ions to produce a phosphorylated enzyme complex. As a result, the hydrolysis of $\mathrm{AChE}$ as the neurotransmitter acetylcholine is slow (Korabecny et al., 2014).

\section{ACETYLCHOLINESTERASE AS NOVICHOK TARGET}

Novichok has the ability to bind with AChE. This binding leads to inhibition of acetylcholine metabolism (Chai et al., 2018). As a member of cholinesterase, AChE has an important site of carboxylic ester hydrolase. AChE catalyses the rapid hydrolysis of acetylcholine to acetate and choline in Ser-His-Glu triangle (Nepovimova et al., 2018, Chai et al., 2018). Instead of acetylcholine hydrolysis, $\mathrm{AChE}$ has another pivotal role in nerve and muscle development, as well as haematopoiesis (Mirjana et al., 2013). Their binding results in acetylcholine abundance. The mechanism of Novichok is described in Figure 4. This situation generates neurotoxicity and severe weakness of the muscle respiratory with symptoms of mydriasis and bronchorrhea which caused breathlessness. Those symptoms might progress rapidly to seizure, paralysis in respiratory, bradycardia, and come, or even death (Chai et al., 2018). Moreover, Novichok binds to peripheral sensory nerves. Prolonged exposure or high dose use of this compound may cause peripheral neuropathy (Smithson et al., 1995, Gupta, 2015).

\section{MOLECULAR MODELLING}

A molecular model can be used to identify the molecular interaction of Novichok while inhibiting AChE by creating the interaction model using the Density Functional Theory (DFT) method with Becke's threeparameter (B3). Serine with a hydroxy group in its structure can be modeled as the active side using both the deprotonated $\mathrm{CH}_{3} \mathrm{O}^{-}$anion and neutral $\mathrm{CH}_{3} \mathrm{OH}$ (Wang et 
$\mathrm{Cl}^{\mathrm{Cl}} \mathrm{P}_{\mathrm{Cl}}^{\mathrm{P}}$<smiles>CC(O)C(C)O</smiles><smiles>CC1OP(Cl)OC1C</smiles><smiles>CC1OP(Cl)OC1C</smiles><smiles>CC1OP(F)OC1C</smiles><smiles>CC1OP(F)OC1C</smiles><smiles>CCCC1O[PH](F)(ON=C(F)Cl)OC1C</smiles><smiles>CI</smiles><smiles>CC(Cl)C(C)OP(=O)(F)N=C(F)Cl</smiles>

Figure 3. Possible synthesis of Novichok from precursors
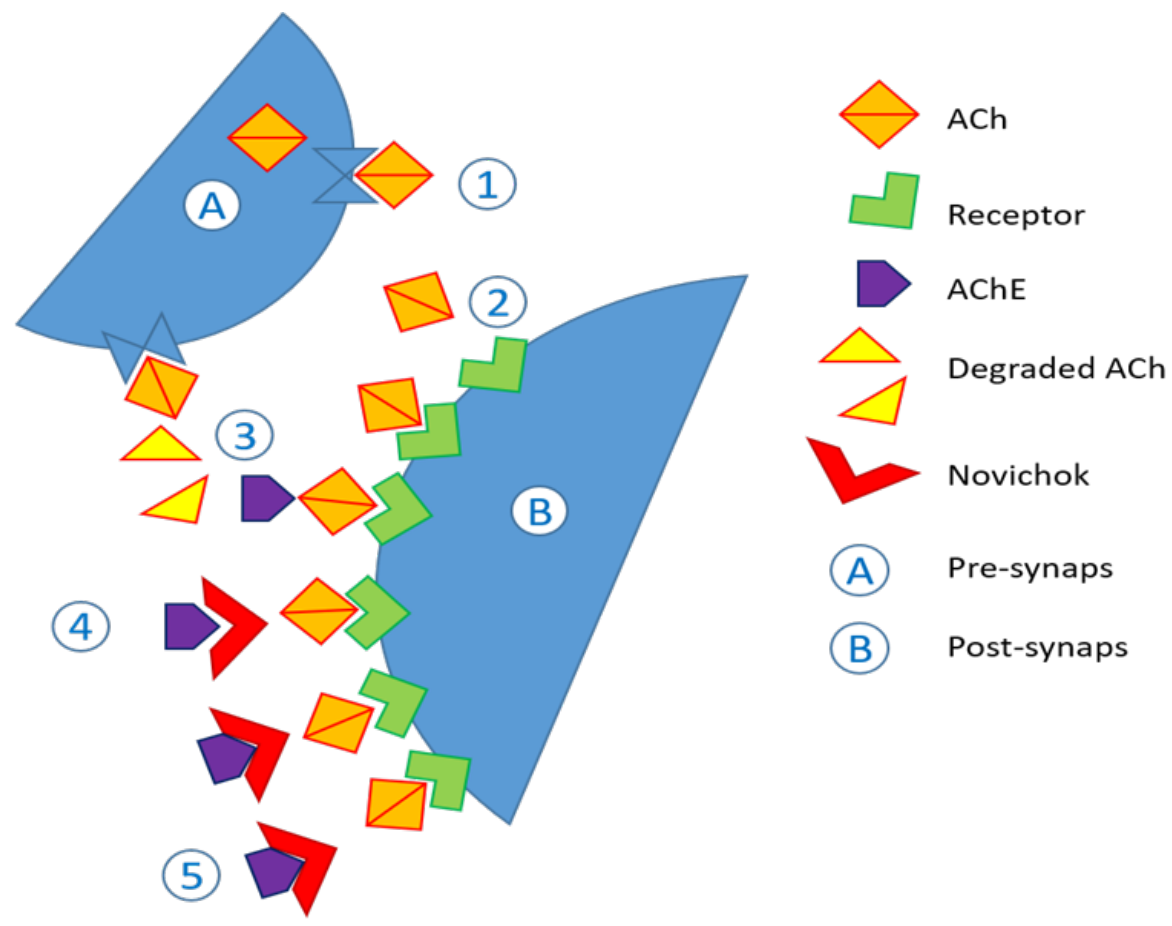

Figure 4. Novichock targets acetylcholinesterase to generate neurotoxicity. 1) Acetylcholine (ACh) released by neuron cell in pre-synapse by exocytosis. 2) They will bind to acetylcholine muscarinic receptor to induce muscle contraction. 3) Acetylcholinesterase (AChE) terminate the signal contraction by degradation ACh. 4) In the present of novichock, it binds to $\mathrm{AChE}$ and refrain it to degrade $\mathrm{ACh}$. Hence $\mathrm{ACh}$ was abundance and generates neurotoxicity and respiratory disorder. 
al., 2006). Organophosphate compounds can interact with AChE, thereby inhibiting its control over the central nervous system. The initiation of AChE occurs because of the phosphorylation of the active serine residue (Khan et al., 2011). Oximate anions compounds can reactivate the phosphorylated $\mathrm{AChE}$ and its effect can be seen computationally using the M06-2X/6-311++G (d,p) model. Two types of oximate anions, formoximate and hydroxylamine anions, were used as models to see the AChE reactivation process. Hydroxylamine anions have better binding affinity to reactivate AChE compared to formoximate anions, which can be seen from the smaller $\Delta \mathrm{H}$ and $\Delta \mathrm{G}$ values (Bhakhoa et al., 2019).

The Novichok A230, A232 and A234 as in Table 1 are known to have the same basic structure, which distinguishes them from the side chains. Novichok A232 has a methyl group substituent and Novichok A234 has 2 methyl group substituents on its side chain which results in increased toxicity of the two compounds compared to Novichok A230 which does not have a methyl group.

\section{POTENTIAL ASSAY PROCEDURE FOR THE IDENTIFICATION OF NOVICHOK}

Variety toxic compounds used in terrorist attacks should be detected using precise methods. A sensitive and selective analytical instrument is required to analyze these compounds, particularly Gas ChromatographyMass Spectrophotometry (GC-MS). Nevertheless, this method requires a standard chemical for identification. On the other hand, Femtosecond Photoionization-Mass Spectrophotometry (FI-MS) provides a molecular ion and fragment ions in most cases (Hamachi et al., 2016). Therefore, the identification of Novichok agents could be performed when the spectral properties are available. Several research shows that a single-channel chip-based analytical microsystem can be used for separation and detection of nerve agent compounds. The protocol involves repetitive rapid flow injection (screening) assay to provide a timely warning and alarm and switching to the separation (fingerprint identification) mode only when harmful compounds are detected (Wang et al., 2002).

\section{NOVICHOK TREATMENT AND POTENTIAL ANTIDOTE}

Directed decontamination is the first important treatment to refrain from further exposure to Novichok. Decontamination by water flushing in skin and clothing exposed will spell out nerve agents. However, increasing $\mathrm{pH}$ of decontamination solution could accelerate Novichok hydrolysis reaction. Dry bleach powder is necessary to be evaded since it can hydrolyze Novichok to become toxic metabolites. This reaction produces hydrofluoric and hydrochloric acid as well as hydrogen cyanide. All those products have toxicity in the cholinergic pathway (Nepovimova et al., 2018).

Moreover, atropine injection is mandatory following decontamination. Atropine is a competitive antagonist of central and peripheral acetylcholine muscarinic receptors. Atropine was administered intravenously (IV) 2-6 mg every 5-10 minutes, up to muscarinic symptoms undertake. Those symptoms are respiratory distress like bradycardia or bronchospasm. Further, Diazepam is needed to prevent and overcome seizures that commonly happened in Novichok poisoning. Another therapy using antihistamine agents, diphenhydramine, is also possible in the absence of atropine, although only tested in rat models of organophosphate intoxication (Chai et al., 2018). Diphenhydramine could be an antagonist for muscarinic acetylcholine receptor (Bird et al., 2002; Eisenkraft \& Falk, 2016).

The antidotes, pralidoxime 1-2 $\mathrm{g}$ and obidoxime $250 \mathrm{mg}$ can be administrated by IV to recover acetylcholinesterase activity (Nepovimova et al., 2018, Chai et al., 2018). For these antidots, human butyrylcholinesterase (huBuChE) was investigated in soman and VX intoxication. Soman, VX, and Novichok were altogether nerve toxic agents.

Table 1. Structure and toxicity of Novichok

\begin{tabular}{lllll}
\hline $\begin{array}{l}\text { Originated structure of } \\
\text { Novichok }\end{array}$ & Side group changed & $\begin{array}{l}\text { Toxicity } \\
\left(\mathbf{L D} \mathbf{m}_{\mathbf{5}} \mathbf{m g} / \mathbf{k g}\right)\end{array}$ & $\begin{array}{l}\Delta \mathbf{G} \\
\left(\mathbf{k c a l ~ m o l} \mathbf{~ m}^{-1}\right)\end{array}$ & Reference \\
\hline & $\mathrm{R} 1=\mathrm{H} ; \mathrm{R} 2=\mathrm{H}(\mathrm{A} 230)$ & 3.52 & 0.427 & \\
& $\mathrm{R} 1=\mathrm{CH}_{3} ; \mathrm{R} 2=\mathrm{CH}_{3}(\mathrm{~A} 234)$ & 3.04 & 0.796 & $\begin{array}{l}\text { (Carlsen 2018, Jeong } \\
\text { \& Choi, 2019) }\end{array}$ \\
\hline
\end{tabular}


Table 2. Novichok treatment and antidotes

\begin{tabular}{|c|c|c|c|c|}
\hline $\begin{array}{l}\text { Name of drug/ } \\
\text { treatment }\end{array}$ & Dosage & Mechanism of action & $\begin{array}{l}\text { Administration } \\
\text { route }\end{array}$ & Reference \\
\hline Atropine & $\begin{array}{l}2-6 \text { mg every } \\
5-10 \text { minutes } \\
\text { until muscarinic } \\
\text { symptoms resolve }\end{array}$ & $\begin{array}{l}\text { Competitively inhibit } \\
\text { muscarinic receptors } \\
\text { and antagonize } \\
\text { parasympathetic effect }\end{array}$ & $\begin{array}{l}\text { Injection } \\
\text { intravenously }\end{array}$ & Chai et al., 2018 \\
\hline Diazepam & $\begin{array}{l}10 \mathrm{mg} \text { up to } 30-40 \\
\mathrm{mg} \text { per } 24 \mathrm{~h}\end{array}$ & $\begin{array}{l}\text { Agonis of gamma } \\
\text { aminobutyric acid } \\
\text { (GABA)-A receptors }\end{array}$ & $\begin{array}{l}\text { Slow injection } \\
\text { intravenously }\end{array}$ & $\begin{array}{l}\text { Bajracharya et al., } \\
2016\end{array}$ \\
\hline $\begin{array}{l}\text { Pralidoxime } \\
\text { (2-PAM) }\end{array}$ & $1-2 \mathrm{~g}$ & $\begin{array}{l}\text { Reactivates the AChE that } \\
\text { has been inactivated by the } \\
\text { organophosphate }\end{array}$ & $\begin{array}{l}\text { Injection } \\
\text { intravenously }\end{array}$ & DeClementi, 2007 \\
\hline Obidoxime & $250 \mathrm{mg}$ & Reactivating AChE & $\begin{array}{l}\text { Injection } \\
\text { intravenously }\end{array}$ & Eyer, 2003 \\
\hline $\begin{array}{l}\text { Human } \\
\text { butyrylcholinesterase }\end{array}$ & $13.1 \mathrm{mg} / \mathrm{kg}$ & $\begin{array}{l}\text { As a bioscavenger for } \\
\text { poisons that might inhibit } \\
\text { AChE activity }\end{array}$ & $\begin{array}{l}\text { Injection } \\
\text { intramuscularly }\end{array}$ & Myers, 2019 \\
\hline Carbamate & $\begin{array}{l}30 \mathrm{mg} 3 \times \text { daily of } \\
\text { the carbamate }\end{array}$ & $\begin{array}{l}\text { Blocking the } \\
\text { phosphorylation of AChE }\end{array}$ & Inhalation & An et al., 2016 \\
\hline
\end{tabular}

To the best of our knowledge, there are several studies considering the use of huBuChE in probable prophylaxis treatments as well as nerve toxic agents postexposure, such as soman and VX (Raveh et al., 1997, Bajgar et al., 2007, Masson \& Nachon 2017, Zhang et al., 2020). Animal studies showed that huBuChE protects against 5,5 times the median lethal dose of another nerve toxic agents, soman and VX (Cerasoli et al., 2019).

Organophosphate (OP) compounds that react with AChE cause the formation of the OP-AChE adduct. There are several strategies that can be used for pretreatment: 1. Protective inhibitor, 2. Scavenger and 3. Reactivator approaches (Broomfield \& Kirby, 2001). Carbamate is an example of a protective inhibitor compound that can block the phosphorylation of AChE. Scavager strategy can be used organophosphorus acid anhydride hydrolase (OPAAH) compounds for example phosphotriesterase, carboxylesterase and paraoxonase. Oxime-induced compounds such as 2-pyridine aldoxime methyl chloride (2-PAM) can be used as reactivation strategies. This 2-PAM compound is more effective for the treatment of OP compounds and has been approved to be used in clinics by the FDA (An et al., 2016). Human butyrylcholinesterase is a glycoprotein composed of four identical subunits. HuBChE can be used for novichok treatment as a bioscavenger for poisons that might inhibit acetylcholinesterasectivity (Myers, 2019). All the treatments were summarized in Table 2.

\section{FUTURE PERSPECTIVE}

Finding a new agent to eliminate binding of Novichok and AChE. In the perspective of chemistry, a more selective and sensitive tool for detecting chemicals for the organophosphate group is needed so that the molecular interactions could be observed. Our review was undertaken to explore the chemical properties and biological activities of Novichok. Chemically, Novichok could potentially be modified to be more toxic in the nervous system. Hence, the toxicity of modified-structure Novichok is remain questionable and need to be explored further. Moreover, the treatment for Novichok need to be explored as the current antidot could not effectively break Novichok and AChE to bind. Therefore, the development of therapy for this compound needs to be examined.

\footnotetext{
ABBREVIATION

CWAs : Chemical Warfare Agents

CWC : Chemical Weapons Convention

OPCW : Organization for Prevention of Chemical Weapon

CWs : Chemical Weapons

AChE : acetylcholinesterase

GC-MS : Gas Chromatography-Mass Spectrophotometry FI-MS : Femtosecond Photoionization - Mass Spectrophotometry
} 
IV : intravenously

DFT : Density Functional Theory

B3 : Becke's three-parameter

HuBuChE : Human butyrylcholinesterase

Ser-His-Glu : serin-histidine-glutamine

2-PAM : 2-pyridine aldoxime methyl chloride

\section{REFERENCES}

An, Y., Zhu, Y., Yao, Y., \& Liu, J. (2016). Is it possible to reverse aged acetylcholinesterase inhibited by organophosphorus compounds? Insight from the theoretical study. Physical Chemistry Chemical Physics : PCCP, 18(14), 9838-9846. https://doi.org/10.1039/ c5cp07991h

Bajracharya, S. R., Prasad, P. N., \& Ghimire, R. (2016). Management of Organophosphorus Poisoning. Journal of Nepal Health Research Council, 14(34), 131-138.

Bajgar, J., Bartosova, L., Kuca, K., Jun, D., \& Fusek, J. (2007). Changes of cholinesterase activities in the rat blood and brain after sarin intoxication pretreated with butyrylcholinesterase. Drug and Chemical Toxicology, 30(4), 351-359. https://doi. org/10.1080/01480540701522395

Bhakhoa, H., Rhyman, L., \& Ramasami, P. (2019). Theoretical study of the molecular aspect of the suspected novichok agent A234 of the Skripal poisoning. Royal Society Open Science, 6(2), 181831. https://doi. org/10.1098/rsos.181831

Bird, S. B., Gaspari, R. J., Lee, W. J., \& Dickson, E. W. (2002). Diphenhydramine as a protective agent in a rat model of acute, lethal organophosphate poisoning. Academic Emergency Medicine, 9(12), 1369-1372. https://doi.org/10.1111/j.1553-2712.2002.tb01604.x

Broomfield, C. A., \& Kirby, S. D. (2001). Progress on the road to new nerve agent treatments. Journal of Applied Toxicology, 21 Suppl 1, S43-S46. https://doi. org/10.1002/jat.804

Brooks, J., Erickson, T. B., Kayden, S., Ruiz, R., Wilkinson, S., \& Burkle, F. M., Jr (2018). Responding to chemical weapons violations in Syria: legal, health, and humanitarian recommendations. Conflict and Health, 12, 12. https://doi.org/10.1186/s13031-018-0143-3

Carlsen L. (2019). After Salisbury Nerve Agents Revisited. Molecular Informatics, 38(8-9), e1800106. https://doi.org/10.1002/minf.201800106

Cerasoli, D. M., Armstrong, S. J., Reeves, T. E., Hodgins, S. M., Kasten, S. A., Lee-Stubbs, R. B.,
Cadieux, C. L., Otto, T. C., Capacio, B. R., \& Lenz, D. E. (2020). Butyrylcholinesterase, a stereospecific in vivo bioscavenger against nerve agent intoxication. Biochemical Pharmacology, 171, 113670. https://doi. org/10.1016/j.bcp.2019.113670

Chai, P. R., Hayes, B. D., Erickson, T. B., \& Boyer, E. W. (2018). Novichok agents: a historical, current, and toxicological perspective. Toxicology Communications, 2(1), 45-48. https://doi.org/10.1080/24734306.2018.14 75151

Colović, M. B., Krstić, D. Z., Lazarević-Pašti, T. D., Bondžić, A. M., \& Vasić, V. M. (2013). Acetylcholinesterase inhibitors: pharmacology and toxicology. Current Neuropharmacology, 11(3), 315335. https://doi.org/10.2174/1570159X11311030006

DeClementi, C. (2007). Veterinary Toxicology: Basic and Clinical. $1^{\text {st }}$ Edition. Academic Press

Eisenkraft, A., \& Falk, A. (2016). The possible role of intravenous lipid emulsion in the treatment of chemical warfare agent poisoning. Toxicology Reports, 3, 202210. https://doi.org/10.1016/j.toxrep.2015.12.007

Ellison, D.H. (2016). Emergency Action for Chemical and Biological Warfare Agents. $2^{\text {nd }}$ Edition. CRC Press.

Eyer, P. (2003). The role of oximes in the management of organophosphorus pesticide poisoning. Toxicological Reviews, 22(3), 165-190. https://doi. org/10.2165/00139709-200322030-00004

Franca, T., Kitagawa, D., Cavalcante, S., da Silva, J., Nepovimova, E., \& Kuca, K. (2019). Novichoks: The dangerous fourth generation of chemical weapons. International Journal of Molecular Sciences, 20(5), 1222. https://doi.org/10.3390/ijms20051222

Gupta, R.C. (2015). Handbook of Toxicology of Chemical Warfare Agents. Academic Press.

Halámek, E., Kobliha, Z. (2011). Potential Chemical Warfare Agents. Chemicke Listy. 105, 323-333.

Hamachi. A., Imasaka, T., Imasaka, T. (2016). Femtosecond ionization mass spectrometry: an advanced tool for the analysis of pollutants, explosives, and nerve agents. 13th Asian Conference on Analytical Sciences. (pp46) Chiang Mai, Thailand

Hoenig, S.L. (2007). Compendium of Chemical Warfare Agents. New York: Springer-Verlag.

Jeong, K., Choi, J. (2019). Theoretical study on the 
toxicity of 'Novichok' agent candidates. Royal Society Open Science, 6: 190414.

Khan, M. A., Lo, R., Bandyopadhyay, T., \& Ganguly, B. (2011). Probing the reactivation process of sarininhibited acetylcholinesterase with $\alpha$-nucleophiles: hydroxylamine anion is predicted to be a better antidote with DFT calculations. Journal of Molecular Graphics \& Modelling, 29(8), 1039-1046. https://doi.org/10.1016/j. jmgm.2011.04.009

Korabecny, J., Soukup, O., Dolezal, R., Spilovska, K., Nepovimova, E., Andrs, M., Nguyen, T. D., Jun, D., Musilek, K., Kucerova-Chlupacova, M., \& Kuca, K. (2014). From pyridinium-based to centrally active acetylcholinesterase reactivators. Mini Reviews in Medicinal Chemistry, 14(3), 215-221. https://doi.org/10 $.2174 / 1389557514666140219103138$

Masson, P., \& Nachon, F. (2017). Cholinesterase reactivators and bioscavengers for pre- and postexposure treatments of organophosphorus poisoning. Journal of Neurochemistry, 142 Suppl 2, 26-40. https:// doi.org/10.1111/jnc. 14026

Mirzayanov, V.S. (2009). State Secrets: An Insider's Chronicle of the Russian Chemical Weapons Program. Outskirts Press, Incorporated.

Myers T. M. (2019). Human plasma-derived butyrylcholinesterase is behaviorally safe and effective in cynomolgus macaques (Macaca fascicularis) challenged with soman. Chemico-Biological Interactions, 308, 170 178. https://doi.org/10.1016/j.cbi.2019.05.021

Nepovimova, E., \& Kuca, K. (2018). Chemical warfare agent NOVICHOK - mini-review of available data. Food and Chemical Toxicology, 121, 343-350. https:// doi.org/10.1016/j.fct.2018.09.015
Raveh, L., Grauer, E., Grunwald, J., Cohen, E., \& Ashani, Y. (1997). The stoichiometry of protection against soman and VX toxicity in monkeys pretreated with human butyrylcholinesterase. Toxicology and Applied Pharmacology, 145(1), 43-53. https://doi.org/10.1006/ taap. 1997.8160

Smithson, A.E., Mirzayanov, V.S., Lajoie, R., et al. (1995). Chemical weapons disarmament in Russia: Problems and prospects. Washington, DC: The Stimson Center. 1-83.

Szinicz, L. (2005). History of chemical and biological warfare agents. Toxicology, 214(3), 167-181

Vale, J. A., Marrs, T. C., OBE, \& Maynard, R. L., CBE (2018). Novichok: a murderous nerve agent attack in the UK. Clinical Toxicology, 56(11), 1093-1097. https://doi. org/10.1080/15563650.2018.1469759

Wang, J., Gu, J., Leszczynski, J. (2006). Phosphonylation mechanisms of sarin and acetylcholinesterase: a model DFT study. The Journal of Physical Chemistry B, 110, $7567-7573$.

Wang, J., Pumera, M., Chatrathi, M. P., Escarpa, A., Musameh, M., Collins, G., Mulchandani, A., Lin, Y., \& Olsen, K. (2002). Single-channel microchip for fast screening and detailed identification of nitroaromatic explosives or organophosphate nerve agents. Analytical Chemistry, 74(5), 1187-1191.

Zhang, L., Murata, H., Amitai, G., Smith, P. N., Matyjaszewski, K., \& Russell, A. J. (2020). Catalytic Detoxification of Organophosphorus Nerve Agents by Butyrylcholinesterase-Polymer-Oxime Bioscavengers. Biomacromolecules, 21(9), 3867-3877. https://doi. org/10.1021/acs.biomac.0c00959 